\title{
Investigations in vitro on the behaviour of chromosomes and the mitotic apparatus in endosperm cells of Haemanthus katherinae Baker treated with oleander glycosides
}

\author{
J. A. TARKOW $>$ KA
}

Laboratory of General Botany, Institute of Botany, Warsaw University, Warsaw

(Received: March 8, 1976)

Abstract

The effect of oleander glycosides on dividing endosperm cells of Haemanthus katherine was investigated in vitro. The disturbances in the successive cell division phases were analysed in reference to cytokinesis. A strong tendency was noted to restitution nuclei formation in all phases of mitosis, and particularly in prophase. The observed chromosome pattern is the result of disturbances in prometaphase and anaphase chromosome movements owing to disturbances in the function of the mitotic spindle. It is probable that oleander glycosides inhibit formation of the microtubules of the mitotic spindle and disorganize the already formed spindle. They cause minor disturbances in cytokinesis, although frequently cell plates arise in quite unexpected places.

The results of the present study are compared with those obtained in the case of root meristematic cells ( $\mathrm{T}$ a rk ow s k a, 1971a, b).

\section{INTRODUCTION}

In $1971 \mathrm{Tarkowska}$ demonstrated the antimitotic properties of the mixture of water-soluble oleander glycosides. Basic investigation and detailed analysis of the action of these compounds were performed on the meristematic cells of root tips of Allium cepa (T a r kow s ka, 1971a, b) and the results were checked on root apical meristems of other plants (T a rkowska and Brześkiewicz, unpublished observations). The effect of glycosides on the division of generative nuclei was also investigated in pollen grains of Allium cepa and Tradescantia bracteata, (T a rkowska and Matuszewska, 1975) and on the development of stomata in Hordeum vulgare (Tarkowska, Wierzbicka and Grze gółka, 1975). 
In all the above mentioned studies disturbances in cell division of always the same kind were noted notwithstanding the type of cells used for the experiments. Anomalies both in karyo- and cytokinesis were observed in the course of the entire cell division. Usually, through scattered meta- and anaphases they lead to the formation of polyploid nuclei or several hypoploid ones or else to the formation of multinucleate cells or cell complexes, frequently with incomplete cell plates.

The appearance of the above mentioned figures which are the result of abnormal chromatin distribution indicates that oleander glycosides must produce essential disorders in the structure and function of the mitotic spindle responsible for chromosome movements during mitosis. This supposition was confirmed by preliminary studies in the electron microscope (EM) of Haemanthus katherine endosperm (T a r k o w s a 1971b). The results are being elaborated in detail.

The mitotic figures observed in the root apical meristem after various times of incubation in glycoside solution gave an only general picture of the direction of the cell division disturbances. Their accurate analysis (succession of changes and variants in them) became possible only in experiments in vitro and it is the subject of the present work. It is believed that detailed observations in vitro suplemented by comprehensive studies in EM will be of general interest since they will reveal the indispensable factors conditioning normal chromosome movements.

Noteworthy is the use of a chemical or physical factor capable of interfering with the formation or function of the mitotic spindle or phragmoplast (or both) indispensable for normal cell division. The multipolar anaphases occurring usually under such abnormal conditions, and, particularly the scattered anaphases and c-mitoses, are of great importance for understanding the mechanism of chromosome movement.

Disorganization of the spindle was investigated among other conditions under the action of methanol and $\beta$-particles (Molè-Bajer 1965), colcemide and colchicine (Brinkley, Stubblefield and $\mathrm{Hsu}$, 1967; Pickett-Heaps, 1967), low temperature (Roth, 1967), chloral hydrate (Molè-B a jer, 1967, 1969), isopropyl N-phenylcarbamate (IPC) (H e pler and J a ckson, 1969), and IPC and melatonin (J a ckson, 1969). The experiments of Molè-Bajer and $\mathrm{Hepler}$ and $\mathrm{Jackson}$ were performed in vitro on Haemanthus katherinae endosperm.

MATERIAL AND METHODS

Endosperm cells of Haemanthus katherinae Baker were studied in vitro. It is particularly convenient for such obsevations on account of the relatively easy culture of these plants, the gradually ripening seeds, the 
large endosperm cells and large, morphologically distinctly differentiated chromosomes.

The observations were carried out during 3 vegetation seasons. Cell division was studied in hundreds of cells, this allowing to avoid randomness in elaboration of the results.

In preparation the technique elaborated and described by Molè - B a jer and B a jer (1968) was followed. Endosperm cells flattened on the medium (hot agar with glucose) and covered with a diffusion film of agar, glucose and gelatin were exposed to an aqueous 0.025 per cent solution of a mixture of oleander glycosides (Oleander Gesamtglycoside, Laborchemikalien, Carl Roth OHG, Karlsruhe-West) added to 3.7 per cent glucose solution used for filling the perfusion chamber. Observations were started 5-10 min after glycoside application.

Division of the chosen healthy well flattened endosperm cells was observed in phase contrast. The microphotographs included in the paper were also taken in phase contrast with the use of a Zetopan-type microscope (Reichert, Austria) and Exacta Varex camera.

\section{RESULTS}

Numerous chemical substances are known which, according to their concentration, cause various types of disturbances in connection with the different degree of damage to the mitotic spindle. For instance substances of colchicine type and others in a sufficiently high concentration causing complete inactivation of the spindle produce - full c-mitosis (L e v a n, 1938). The same compounds used in lower concentrations eliciting only partial spindle inactivation give various kinds of intermediate disturbances between full c-mitosis and normal mitosis, for instance multipolar anaphases. The intermediate type disturbances have been named partial c-mitosis (Östergren 1944, 1950). The effects of the given compound also depend on the time of exposure of the cell and the plant species. Various species respond differently to the same substance.

The duration of mitosis and of its particular phases in endosperm cells of Haemanthus, even in control material and under the same conditions (and in the same preparation) depend on many factors, among other things on the degree of flattening of the cells. As reported by Molè- B a jer (1967) flattening itself may prolong mitosis two or even three times.

The degree of flattening of the endosperm also affects the viability of the cells. It may be generally affirmed that less flattened cells live longer, but the disturbances in division of such cells are less obvious. On the other hand, in strongly flattened cells, though less viable and undergoing sooner vacuolization, it is easy to observe the kind and 
succession of the changes. It seems that the size of the cell, that is the area available to the chromosomes is not without meaning here, although Molè-Bajer stresses that inhibition of chromosome movement cannot be explained by the restricted space.

Flattening of the cells may cause their vacuolization. Even strong but uniform vacuolization of the peripheral cell parts (Plate IV, figs $3-6$ ) does not interfere with division of the nucleus or prolong the time of mitosis. On the other hand, single, strongly enlarging vacuoles forming at random sites in the cytoplasm are symptoms of pathological changes in the cell and cause inhibition of its division.

The present observations indicate that the effect of glycosides depends on the division phase of the nucleus at the moment of contact with these substances. This is decisive to the further course of nucleus and total cell division, and also for the time at which the elicited anomalies will be noticeable in the light microscope. For instance the consequences of exposure to the above named substances at prometaphase become manifest after 2 or even $3 \mathrm{hrs}$, whereas the results after treatment at anaphase appear as early as after $30 \mathrm{~min}$. Both these cases show the different sensitivity of the particular mitosis phases to the action of glycosides.

\section{Prophase}

Early- and medium-prophase nuclei subjected to the action of oleander glycosides do not as a rule divide any further. Around the nuclear envelope a narrow isodiametric clear zone may form (mitochondria, plastids and all granular material disappear from the area), but even in the elongated cells polar caps do not develop. Only when the glycosides were applied at very late prophase was the clear zone around the entire nucleus wider, and in the elongated cells slightly conical towards the future poles of the cell. Within the nucleus chromosome movements occur, leading to a loosening of its structure, but finally restitution nuclei are formed. The clear zone disappears very soon.

\section{Prometaphase and metaphase}

Both phases are markedly prolongated: in normal (control) mitosis in the flattened Haemanthus endosperm the prometaphase lasts on the average $110 \mathrm{~min}$ and metaphase 45 to $60 \mathrm{~min}$. Under the action of oleander glycosides the prometaphase is prolonged to $150-250 \mathrm{~min}$ and metaphase to $80-120$ min (mean values from ca. 30 cells).

The effect of glycosides on prometaphase is particularly important for the further steps of nucleus and cell division, because this is the period 
of essential and intensive movements of the chromosomes and of final formation of the mitotic spindle. This influence involves both the chromosome movements and their structural modifications.

In prometaphase, like in prophase, there is a tendency to restitution nuclei formation, which is the stronger the less advanced were the prometaphase transformations at the moment of contact of the cells with glycosides. At the middle of prometaphase there is already some chance that nucleus division will continue although with serious disturbances. Sometimes for 2-3 hrs no changes are observed within the nucleus, and only after this time chromosome movements begin: first only their looseness and further translocation which may lead to three different patterns:

1. Movement of whole chromosomes with distinct orientation of the kinetochores towards the equatorial part of the cell - a more or less normal metaphase plate arises then;

2. Erratic movement of chromosomes, the centromeres oriented in various directions. A scattered pattern arises as shown in figs $1-2$ (Plate I) where the whole cell area is interspersed with chromosomes;

3. A chromosome pattern intermediate between 1 and 2. Groups form (usually 3-5) of a random number of chromosomes (Plate II, fig. 1). The patterns resemble multipolar anaphase, but the chromosomes are undivided in the kinetochores. A particular case is what is known as somatic reduction also observed in root meristematic cells ( $\mathrm{T}$ a r k o w s k a, 1971b).

In further transformations formation of restitution nuclei is observed in all the three chromosome systems, or else the structural changes in the chromosomes lead to a metaphase structure with distinct chromatids and centromeres.

The scattered chromosome arrangement in prometaphase or metaphase gives as a rule one polyploid nucleus (the whole of Plate I). On the other hand, grouped chromosomes usually result in the formation of several hypoploid nuclei (micronuclei). Since such groups are usually joined by bridges, and the latter are not always interrupted by the forming cell plates of else these plates do not form between them, these joined groups may merge into one large nucleus (Plate II, figs 1-3). In extreme cases one polyploid nucleus is formed. As a result the formation of several micronuclei is accompanied by the appearance of narrow phragmoplasts between some random groups of chromosomes, this leading finally to protoplast formation with hypoploid nuclei and incomplete cell plates. Analogous transformations leading to formation of restitution nuclei or several micronuclei may occur when the scattered, or agglomerated in groups metaphase chromosomes undergo longitudinal division into chromatids, that is when they are anaphase chromosomes. This longitudinal division of metaphase chromosomes without formation of the characteristic metaphase plate was observed in Haemanthus very often (Plate I). 
Metaphase disturbances (with metaphase plate occurrence) depend on whether the glycosides act directly on metaphase or earlier. In the latter case disturbances noted in further phases are more numerous and varied. When the cell is exposed to glycosides in metaphase, usually two- or multipolar anaphases arise giving, respectively, equipollent nuclei or a few daughter nuclei of different sizes. Division of kinetochores may not take place, and, consequently, restitution nuclei are formed. Plate III, figs $1-6$ show a metaphase cell exposed to glycosides. The successive figures show the course of transformations leading finally to the formation of a polyploid nucleus irregular in shape with some small cell plates (arrows) almost within the nucleus. Similarly in fig. 6 (Plate V) the cell plate is visible within the nucleus. In this case the glycosides were applied at prometaphase.

\section{Anaphase and telophase}

Analogously as in the case of metaphase, disturbances in these phases of nucleus division may be the consequence of disorders in earlier phases of divison or the result of glycoside action directly on anaphase or telophase.

As already mentioned, metaphase chromosomes may divide longitudinally in any position in the cell: in the equatorial plate, scattered almost all over the cell or after formation of chromosome groups. Only when the chromosomes forming the metaphase plate divide longitudinally (independently of the time at which the action of glycosides began) more or less normal anaphase chromosome movements may occur. They usually lead to the formation of two sister equipollent nuclei, although cytokinesis in such cell often takes place with irregularities (Plate $\mathrm{V}$, figs 1-2 and 3-4). There is, however, so high a tendency to restitution nuclei formation that even the started anaphase movements may be arrested and one polyploid nucleus form (Plate II, figs 4-6).

The formation of multipolar anaphases observed after exposure to various chemical compounds as for instance chloral hydrate or colchicine may occur in the investigated material after the action of glycosides in any of the above named metaphase chromosome patterns (sporadically in a scattered system). The action of glycosides must, however, start earlier, before division reaches anaphase. Multipolar anaphases (mostly 3-5) usually joined by chromatid bridges give hypoploid nuclei with a varying random chromosome number. Besides, as already mentioned, the number of micronuclei formed may be smaller than the number of chromosome groups (and number of poles), and the associated cytokinesis disturbances lead to various figures at the end. An example of such disturbances is given in Plate IV, figs 1-6. 
Like in earlier phases, oleander glycosides also prolong anaphase and they protract it the more the stronger are the disturbances. Bipolar anaphase lasts on the average 45-60 min, and multipolar anaphase $120 \mathrm{~min}$ (mean from ca. 30 cells), whereas normal anaphase in Haemanthus lasts 40-45 $\mathrm{min}$.

In healthy dividing endosperm cells all the cell structures visible in phase contrast as granules (mitochondria, proplastides, frequently very numerous starch grains) are grouped as a rule on the cell periphery. They usually accumulate at the future (prometaphase) or already developed cell poles (metaphase, anaphase (Plate II, fig. 4). The first noticeable signal that further nucleus division is arrested is the translocation of the granules to the immediate neighbourhood ofthe chromosomes (Plate II, fig. 5). This is particularly well visible during the formation of restitution nuclei. The granules translocate as if following the aggregating chromosomes, giving the impression that they press and push them. In the peripheral parts of the cell the granules are much scarcer and sometimes almost invisible (Plate II, fig. 6).

\section{Cytokinesis}

In normal cytokinesis the formation of phragmoplasts and cell plates starts at mid anaphase and lasts to the end of telephase. Phragmoplasts begin as continuous fibres of the mitotic spindle and develop and start functioning as new fibres are added. Thus, phragmoplast is not formed de novo, but it is a direct continuation of the mitotic spindle. Phragmoplasts may, however, form without any connection with the spindle or even the nucleus.

Oleander glycosides disturb greatly cytokinesis. The place of fragmoplast formation may be unexpected and accidental. It often gives the impression of not being associated with the presence of the mitotic spindle. The lack of connection with the spindle would seem to indicate the formation of cell plates at the restitution nuclei. These plates would form from the scattered system of chromosomes (prometaphase, metaphase or anaphase ones). The presence in these cases of spindle remains or at least of very short and scarce kinetochore fibres cannot, however, be excluded. This supposition is based on the pictures observed in the light microscope in meristematic cells of onion roots ( $\mathrm{T}$ a rkowska 1971a). The chromosome scattered all over the cell give usually one polyploid nucleus of irregular shape with several short cell plates at the edge (Plate II, fig. 6; Plate III, fig. 6 - arrows) or even within the deformed nucleus (Plate V, fig. 6). In the formation of hypoploid nuclei similar narrow phragmoplasts appear between the chromosome groups joined mostly by bridges. The forming cell plates transect these bridges (Plate III, fig. 5; 
Plate IV, figs 3-5 - arrows), they interrupt them, and owing to this, protoplast is formed with incomplete short cell plates and several micronuclei of unequal size (Plate II, fig. 3; Plate IV, figs 4-6). The short cell plates may also cut off chromatinless areas of the cytoplasm (Plate V, figs 2-4). An abnormal course of cytokinesis was also observed in almost normal bipolar anaphases and telophases. The cell plates formed between sister nuclei are also too short to reach to the edges of the mother cells so that they do not divide them into two daughter cells. The new plates, even when long enough, usually do not run in straight line along the equatorial part of the cells, but are undulating (Plate V, fig. 5), curved at the ends or forked (Plate V, fig. 2). In the examined flattened endosperm cells of Haemanthus formation of complete cell plates dividing the mother cells was not observed in the present investigations. Thus the cell complexes observed in root meristematic cells did not form ( $\mathrm{T}$ a rkowska 1971a, b; Tarkowska and Brześkiewicz - unpublished work). Although the course of cytokinesis may run with severe disturbances, the phase of mitosis in which it occurs is as a rule similar to that in control cells. Phragmoplast differentiation is associated with anaphase-telophase structural transformations of chromosomes, irrespective of their arrangement in the cell.

In the flattened endosperm cells subjected to the action of glycosides the cell plates develop usually from the centre towards the cell periphery, that is inversely to the descriptions and films of $\mathrm{B}$ a jer. The centrifugal direction of development is well visible in long cell plates, whereas very short ones form almost simultaneously on their whole length. Cell plate formation is always preceded by accumulation of granules on this area, their concentration and merging, this giving a continuous structure. The entire process runs very quickly.

\section{DISCUSSION AND CONCLUSIONS}

Studies in vitro of the effect of oleander glycosides on dividing endosperm cells of Haemanthus supply interesting data on the course of mitosis and, particularly, chromosome movement and cytokinesis. They do not, however, explain the immediate causes of abnormal cell division. This problem has to be investigated in the electron microscope.

Glycosides prolong the time of nucleus division in endosperm cells. It was found that even in control conditions wide variations occur in the duration of mitosis. Moreover, on account of the strong tendency to restitution nuclei formation, it was not possible to follow the entire division of one and the same cell subjected to the action of glycosides. On the basis of analysis of several score of dividing cells it may, however, be affirmed that independently of the conditions of observation in vitro, these 

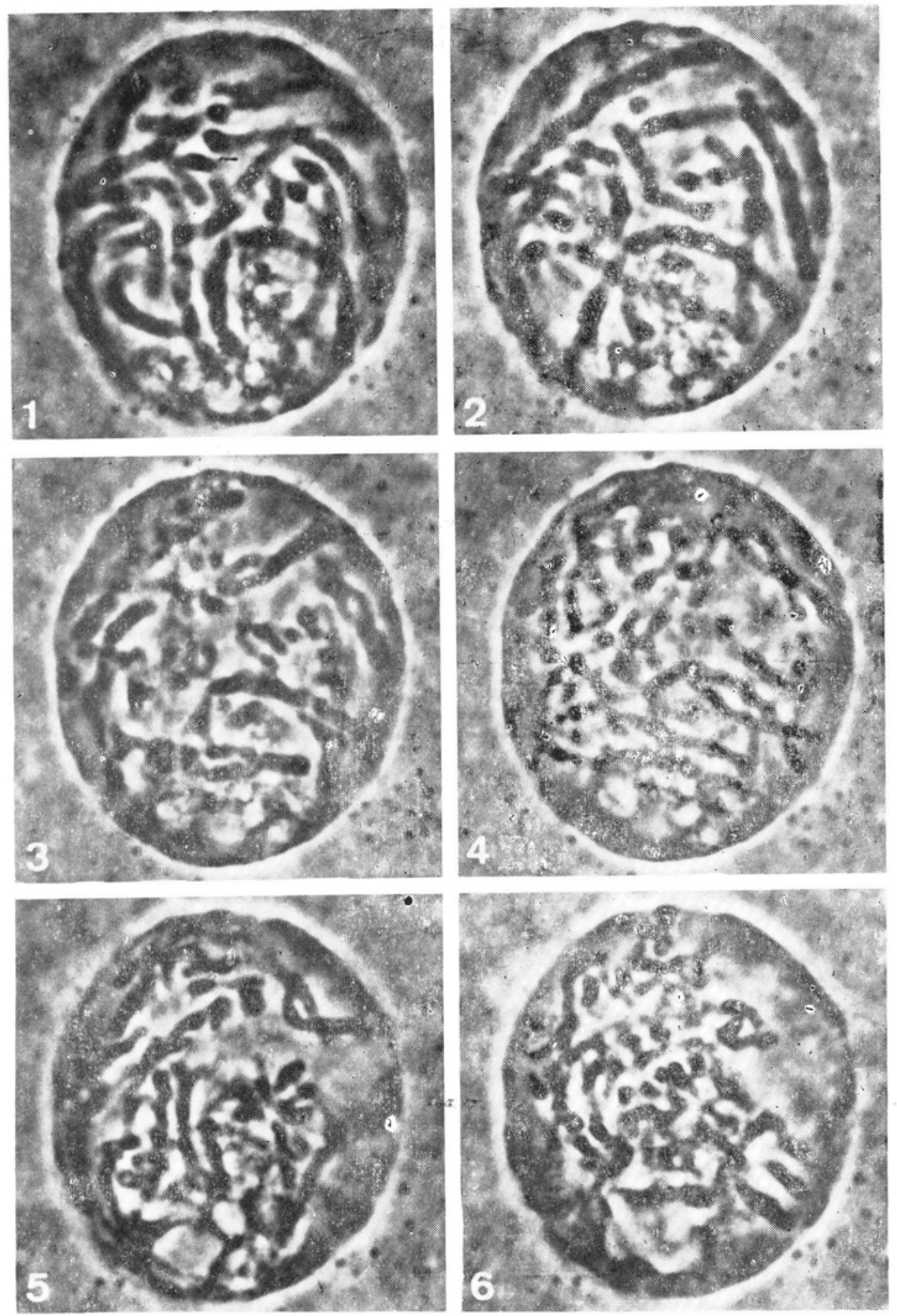

The action of cleander glycosides on prometaphase

$$
\text { N.agn. ca } \times 2.000 \text {. Time counted from fig. } 1
$$

Fig. 1. Chromohomes scattered all over the cell. Fig. 2. $30 \mathrm{~min}$, chromosomes mo:e loosen. Fig. 3. $50 \mathrm{~min}$, uncoiling of chromatids. Fig. 4. $1 \mathrm{~h} 20 \mathrm{~min}$, nearly completed separation of chromatids. Fig. 5. 2 hrs, the distribution of chromosomes related to multipsla: anaphase. Fig. 6. 3 hrs $20 \mathrm{~min}$, the formation o: restitution nucleus 

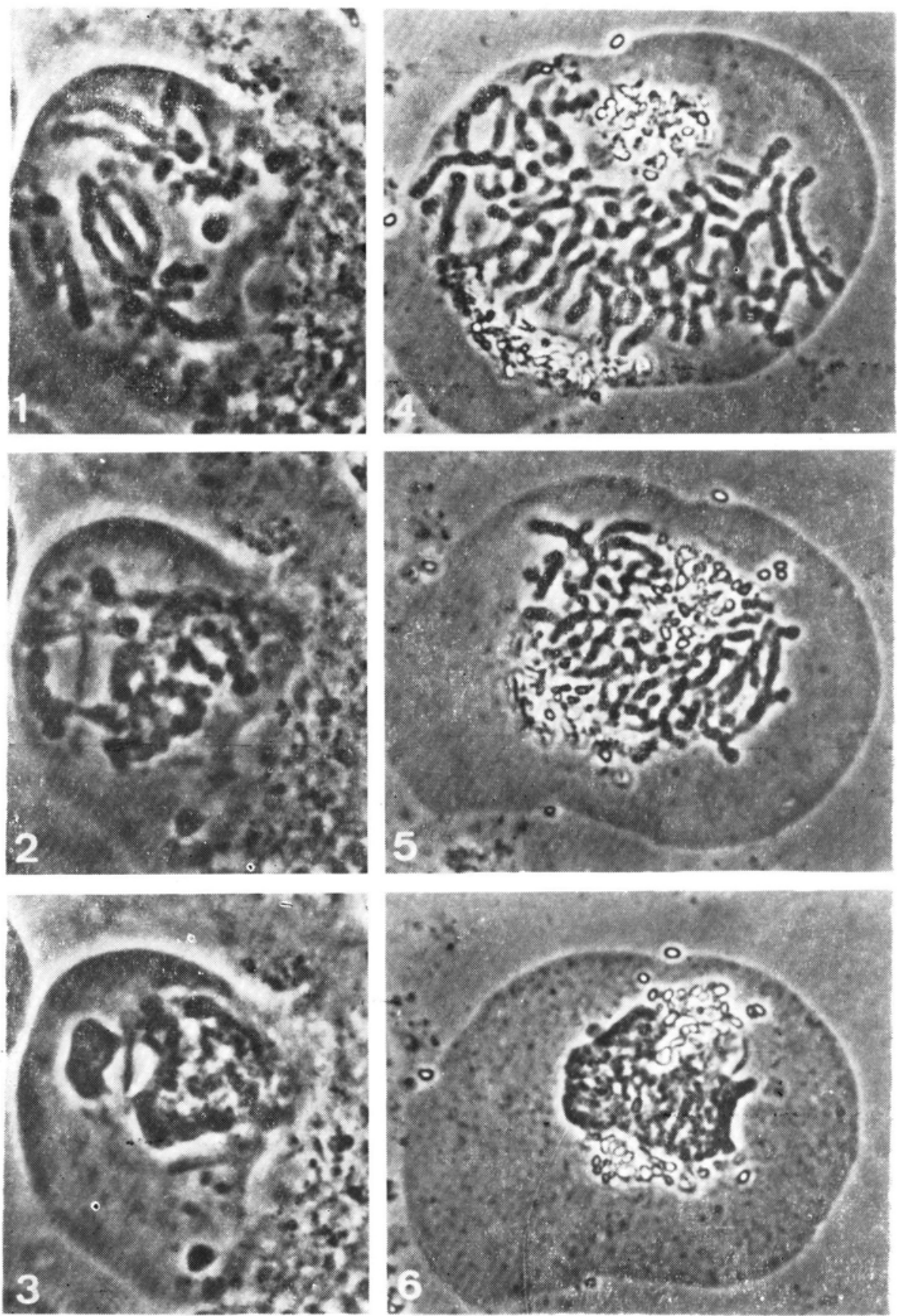

The formation of restitution nuclei. Magn. ca $\times 1.500$

For figs $1-3$ time counted from fig. 1; for figs $4-6-$ from fig. 4 .

Fig. 1. The groups of metaphase chromosomes. Fig. 2. $1 \mathrm{~h} 10 \mathrm{~min}$, the formation of restitution nuclei, a chromosomal bridges and cell plate are visible. Fig. 3. 2 hrs 10 min, two nuclei of different size separated by short cell plate, the second plate outside the nucleus (arrow). Fig. 4. Early anaphase, granules on both cell poles. Fig. 5. $35 \mathrm{~min}$, aggregation of anaphase chromosomes followed they translocation of the granules. Fig. 6. $1 \mathrm{~h} 15 \mathrm{~min}$, polyploid nucleus, the granules in the neighbourhood of the nucleus. Very sho:t cell plate outside the nucleus 

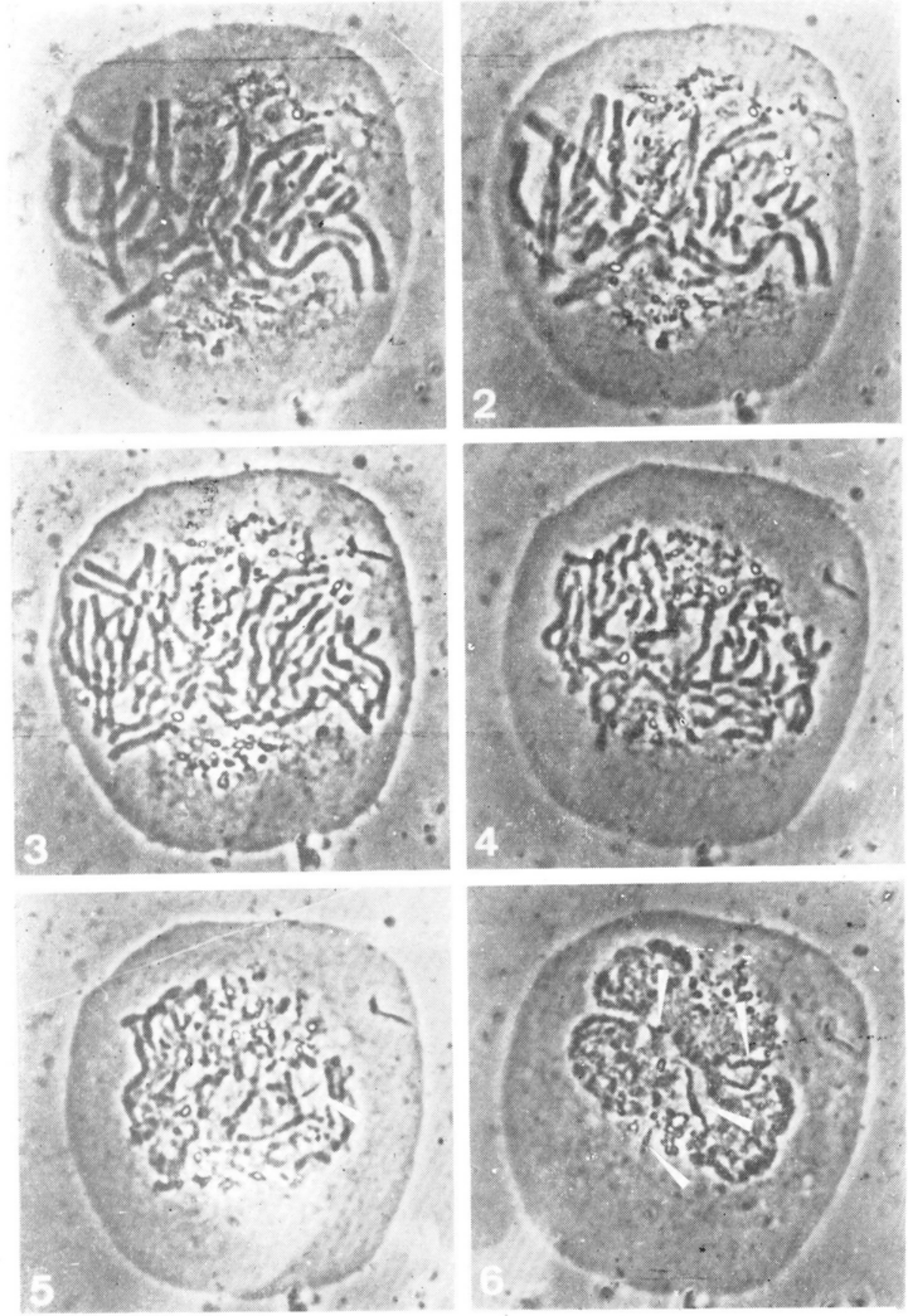

The action of glycosides on the metaphase. Magn. ca $\times 1.500$.

Time counted from fig. 1.

Fig. 1. Nearly normal metaphase plate. Fig. 2. $15 \mathrm{~min}$. very early anaphase. Fig. $3.35 \mathrm{~min}$, disturbances in anaphase chromosome movements. Fig. $4.1 \mathrm{~h} 25 \mathrm{~min}$, aggregation of the chromosomes in the middle part of the cell. Fig. $5.1 \mathrm{~h} 45 \mathrm{~min}$, the formation of the cell plate (arrow), Fig. 6. 2 hrs $45 \mathrm{~min}$, inregular shaped polyploid nucleus with several short cell plates 

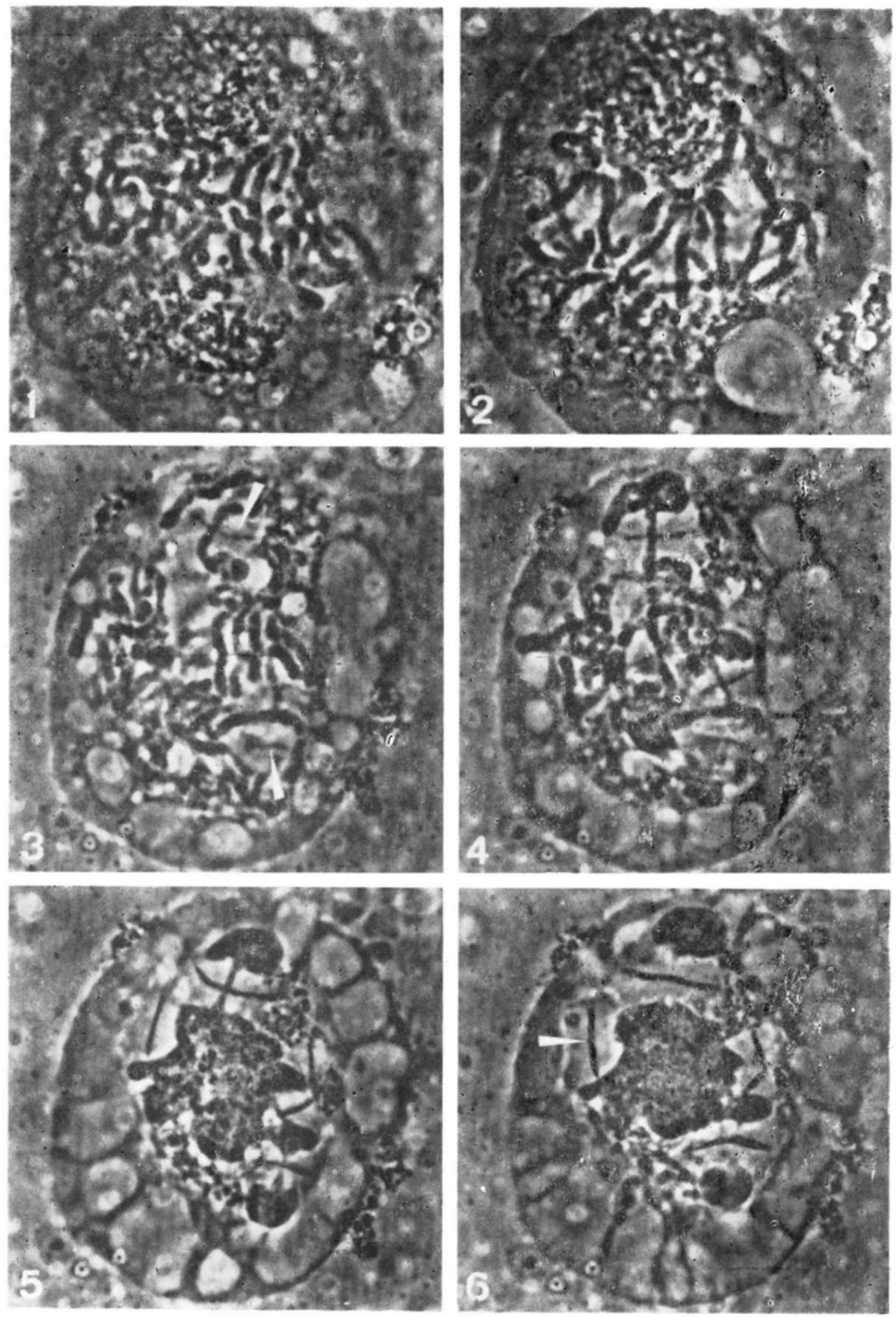

The action of glycosides on early anaphase. Magn. ca $\times 1.500$. Time counted from fig. 1.

Fig. 1. Nea:ly normal early anaphase. Fig. 2. $20 \mathrm{~min}$, multipolar anaphase, chromatid bridges. Fig. 3. $35 \mathrm{~min}$, the formation of cell plates (arrows). Fig. 4. $55 \mathrm{~min}$, the cell plates cut the bridges, structural changes in the chromosomes. Fig. $5.1 \mathrm{~h} 35 \mathrm{~min}$, futher structural changes. Fig. 6. 2 hrs $10 \mathrm{~min}$, three micronuclei, short cell plates between them and two cell plates cutting of achromatic cytoplasmic regions (arrows). 

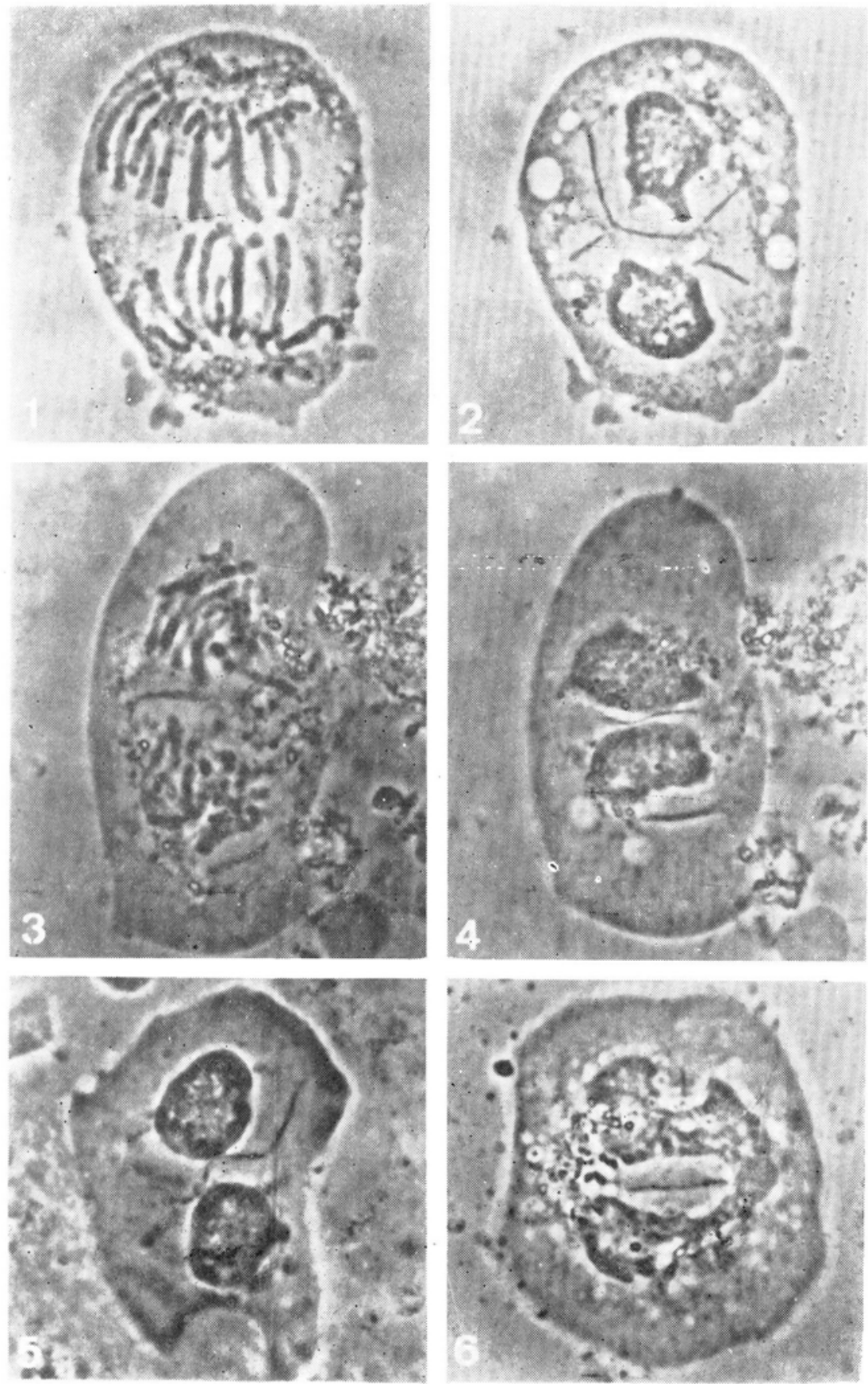

Disturbances in the cytokinesis. Magn. ca $\times 2.000$.

Fig. 1 and 2. Fig. $2-1 \mathrm{~h} 15 \mathrm{~min}$, after Fig. 1, incomplete splited on ends cell plate. Figs 3 and 4. Fig. $41 \mathrm{~h} 15 \mathrm{~min}$, after Fig. 3, short cell plate between sister nuclei and cell plate outside of the nucleus. Fig. 5. Incomplete and zigzagg cell plate. Fig. 6. The cell plate within the polyploid nucleus. 
compounds protract the duration of mitosis at least two times. It should be mentioned that distinction between the particular mitosis phases is very difficult. Therefore, from the aspect of the structure, and not the chromosome arrangement in the cell, it is more correct to speak of metaphase or anaphase chromosomes than of metaphase or anaphase.

In all the investigated cell types (apical root meristem, endosperm, pollen grain, mother cells of stomata) oleander glycosides induce polyploid restitution nuclei formation. This is evidence of such damage to the cell, which makes its further division impossible. In the endosperm early-prophase nuclei exposed to glycosides do not divide further as a rule. In view of the very narrow clear zone or its absence, it may be supposed that the mitotic spindle does not form.

The glycosides are but weakly toxic - the endosperm cells survive 10-12 hrs (after some time the preparations are destroyed by bacteria), and roots may survive as long as 48-hrs incubation, when transferred to water they resume division. Micronuclei containing sometimes only 2 chromosomes also divide ( $\mathrm{T}$ a r k ow s k a, 1971a).

In endosperm cells the disturbances visible in the light microscope appear much sooner than in the meristamatic cells. This may be due to an easier penetration of the solution since endosperm cells do not have cellulose cell walls and glycosides act directly upon the flattened cells. In the root, on the other hand, they must penetrate through the cellulose walls of the cells forming the tissue. The action of the solution is slower here and less drastic. In root meristem complete arrest of mitoses accurs as late as after $48 \mathrm{hrs}$ of incubation. Up to this time not only mitoses started before incubation come to an end, but other cells start division, although in the neighbouring already dividing cells serious disturbances appear. Thus, for $48 \mathrm{hrs}$ there still exist conditions for starting new divisions. This is an essential difference in both the objects studied and it may perhaps be explained by the different sensitivity of these cells.

Another difference concerns the shortening of chromosomes: in meristematic root cells of all the examined plants (including Haemanthus) this process is very distinct after $6 \mathrm{hrs}$ of incubation and may attain a reduction to 30-40 per cent of the control length. In endosperm cells in spite of high sensitivity to glycosides, the changes in length are slight.

The essential disturbances caused by oleander glycosides independently of the material used for experiments are above all disorders in the prometaphase and anaphase chromosome movements and in the mode of cell plate formation.

In prometaphase erratic multidirectional movements, slowed down or completely inhibited were observed, this leading to the appearance of the figures described in the foregoing chapter. It seems, that this behaviour of chromosomes is connected with their considerable disorganization or even perhaps complete inactivation of the mitotic spindle. Literature data 
confirm this supposition. Chromosomes which do not form metaphase plates are scattered or multipolar anaphases as the result of spindle disorganization have been described by B i e s e l e (1958), M o l è - B a j e r (1965, 1967), Kihlman (1966), Brinkley et al. (1967), J a ckson (1969) and others. It results from the papers of the quoted authors that although all disturbances of this type are due to damage to the spindle, the degree and kind of its damage may differ and depends on the agent applied, as demonstrated by submicroscopic investigations. It may be destruction of the whole mitotic spindle or some kind of fibres of a certain type or only disturbance of the parallel arrangement of the microtubules (MTs). Which type of damage is produced by oleander glycosides may be demonstrated by further EM studies.

The direct action of glycosides on metaphase and anaphase causes disturbances in the anaphase movement of the chromosomes, thus at a time when the mitotic spindle is already completely formed. The formation of restitution nuclei, multipolar anaphases and prolongation of the time of metaphase-telophase transformations are evidence that glycosides also disorganize the already developed spindle. If they destroy continuous fibres as demonstrated in preliminary EM studies ( $\mathrm{T}$ a $\mathrm{r}$ k o w s k a, 1971b), it is clear that these fibres must play an essential role in the mechanism of anaphase movements leading to a uniform distribution of chromatin in the two daughter cells. It would seem that the kinetochores, themselves loose their specific activity involved in production of kinetochore fibres and making movement possible.

Oleander glycosides like methanol (M o lè-B a jer, 1965) or chloral hydrate (M ol è-B a jer, 1967) greatly disturb cytokinesis in diving endosperm cells of Haemanthus. Narrow phragmoplasts and short cell plates are formed, frequently in unexpected places in the cell. They do not completely divide the mother cell into daughter cells. In the case of glycosides application, the moment of phragmoplast appearance is always connected with the anaphase-telophase structural transformations of the chromosomes, notwithstanding their arrangement in the cell. The appearance of phragmoplasts should not, however, ke referred to chromosome translocation. They play no active role, on the contrary they may be surrounded by the concentrating chromosomes and "locked" inside the nucleus (Plate V, Fig. 6). M o l è-B a j e r (1967) attributes an active role in chromosome separation to the multipolar phragmoplasts arising in endosperm cells subjected to the action of chloral hydrate.

It is generally considered that the MTs structure of the mitotic spindle and phragmoplast (subunits, their arrangement and size) are the same. Numerous authors (Inoué and B a jer, 1961; and, particularly, Hepler and J a cks on, 1968, and others) even suggest that towards the end of mitosis the MTs of the spindle may undergo depolymerization and translocate into the interzonal area where they are polymerized as 
phragmoplast MTs. Similarly, during development of the cell plate they may disintegrate at the site where the latter formed and reform once more (from the disintegrated parts) at sites of new phragmoplast activity.

The use of various chemical agents shows the different sensitivity of the MTs of the spindle and phragmoplast. Evidence of this is found in experiments with chloral hydrate and in the present investigation on oleander glycosides. On the other hand, substances are known such as for instance caffeine (G i m én e z-M a r tín et al., 1967) or thymol (S z u le$\mathrm{t} a$, personal communication) which make normal functioning of phragmoplast impossible, this leading to the formation of binuclear cells. Separation of chromatin to the daughter nuclei runs normally, that means that the mitotic spindle is not damaged. Similarly the selective action of colcemide on aster MTs (G elfant, 1963) shows their specific sensitivity. These may be only differences in sensitivity to the agent applied, or - what is more probable - other factors may play a role here such a polymerizability of the subunits, cytoplasm movement or a whole complex of factors acting jointly. This problem requires special investigation in detail.

Acknowledgment:

I would like to thank prof. dr J. Szuleta for his comments, criticism and discussions during the writing this paper.

\section{REFERENCES}

Biesele J. J., 1958. Mitotic poisons and the cancer problem, Elsevier Publ. Co.. Amsterdam.

Brinkley B. R., Stubblefield E. and Hsu T. C., 1967. The effect of colcemid inhibition and reversal on the fine structure of the mitotic apparatus of Chinese hamster cells in vitro, J. Ultrastr. Res. 19: 1-18.

G e $1 \mathrm{f}$ a $\mathrm{n}$ t S., 1963. Inhibition of cell division: a critical and experimental analysis, Int. Rev. Cytol. 14: 1-39.

Giménez-Martín G., M eza I., López-Sáez J. F. and Gonzáles-Fer$\mathrm{n}$ á ndez A., 1967. Kinetics of binucleate cell production by caffeine, Cytologia 34: $29-35$.

Hepler P. K. and J a ckson W. T., 1968. Microtubules and early stages of cell-plate formation in the endosperm of Haemanthus katherinae Baker, J. Cell Biol. 38: 437-446.

H e pler P. K. and J a cks on W. T., 1969. Isopropyl N-phenylcarbamate effects on spindle microtouble orientation in dividing endosperm of Haemanthus katherinae Baker, J. Cell Sci. 5: 727-743.

In o ué S. and B a jer A., 1961. Birefringence in endosperm mitosis, Chromosoma 12: $48-63$.

$\mathrm{J}$ a cks o n W. T., 1969. Regulation of mitosis. II. Interaction of isopropyl N-phenylcarbamate and melatonin, J. Cell Sci. 5: 745-755.

Kihlman B. A., 1966. Actions of chemicals on dividing cells, Prentice - Hall. Inc. New Jersey. 
Levan A., 1938. The effect of colchicine on root mitosis in Allium, Hereditas 24: $471-486$.

M o l è-B a jer J., 1965. Telophase segregation of chromosomes and amitosis, J. Ce1l Biol. 25: 79-93.

M o l è-B a jer J., 1967. Chromosome movements in chloral hydrate treated endosperm cells in vitro. Chromosoma 22: 465-480.

M o l è-B a jer J., 1969. Fine structural studies of apolar mitosis, Chromosoma 26: $427-448$.

M o l è-B a jer J. and B a jer A., 1968. Studies of selected endosperm cells with the light and electron microscope the technique, La Cellule 67: 257-265.

Östergren G., 1944. Colchicine mitosis, chromosome contraction, narcosis and protein chain folding, Hereditas 30: 429-467.

Östergren G., 1950. Cytological standards for the quantitative estimation of spindle disturbances, Hereditas 36: 371-382.

Pickett-Heaps J. D., 1967. The effects of colchicine on the ultrastructure of dividing plant cells, xylem wall differentiation and distribution of cytoplasmic microtubules, Develop. Biol. 15: 206-236.

Roth L. E., 1967. Electron microscopy of mitosis in Amebae. III. Cold and urea treatments: A basis for tests of direct effects of mitotic inhibitors on microtubule formation, J. Cell Biol. 34: 47-60.

T a r k ow s ka J. A. 1971a. Effect of water extract from leaves of Nerium oleander L. on mitosis, Acta Soc. Bot. Pol. 40: 623-631.

T a r k owsk a J. A., 1971b. Antimitotic action of glycosides of Nerium oleander L., Hereditas 67: 205-212.

T a rkowska J. A. i Brześki ew i c z W. - unpublished

Tarkowska J. A. and M a tuszewska D., 1975. The effect of oleander glycosides on the germination of pollen grains and the mitosis of the generative nucleus in Tradescantia bracteata Small and Allium cepa L., Acta Soc. Bot. Pol. 44: $451-460$.

Tarkowska J. A., Wierzbicka M. and Grzegółka M., 1975. Developmęnt of stomata in Hordeum vulgare L, under the influence of oleander glycosides and colchicine, Acta Soc. Bot. Pol. 44: 637-647.

\author{
Author's address: \\ Dr Jadwiga A. Tarkowska \\ Laboratory of General Botany \\ University of Warsaw, \\ Krakowskie Przedmieście 26/28 \\ 00-927 Warsaw; Poland
}

Badania in vitro nad zachowaniem się chromosomów i aparatu mitotycznego w komórkach bielma Haemanthus katherinae Baker traktowanych glikozydami oleandra

\title{
Streszczenie
}

Badano in vitro działanie wodnego roztworu mieszaniny glikozydów oleand:a na dzielące się komórki bielma Haemanthus katherinae Baker. Preparaty przygotowywano wg techniki opracowanej przez Molè-Bajer i Bajer (1968). Na rozpłaszczone na pożywce komórki bielma przykryte błoną dyfuzyjną działano $0,025^{\circ} / 0$ 
roztworem glikozydów. Obserwacje rozpoczynano w 5-10 minut po dodaniu roz-tworu.

Analizowano zaburzenia we wszystkich fazach mitozy z uwzględnieniem cytokinezy. Stwierdzono silną tendencję do powstawania jąder restytucyjnych w całym okresie podziału komórki, a szczególnie w profazie.

Jądra profazowe poddane działaniu glikozydów nie dzielą się dalej. Zaburzenia prometafazowe mogą prowadzić do trzech różnych układów chromosomów: tworzenia mniej lub bardziej regularnej płytki metafazowej, powstawania grup chromosomów lub chromosomów rozproszonych na terenie niemal całej komórki. Ten osta ni przypadek daje zwykle jądra restytucyjne, natomiast grupy chromosomów prowadzą do powstawania jąder hypoploidalnych (mikrojąder). Przy działaniu glikozydów na metafazę lub anafazę powstają najczęściej wielobiegunowe anafazy, a z nich mikrojądra, albo 2-biegunowe anafazy - dające dwa równoważne jądra potomne. Rozpoczęte anafazowe przemieszczenia chromosomów mogą być jednak zatrzymane $\dot{i}$ utworzone zostanie jedno jądro poliploidalne.

Zaburzenia w cytokinezie dotyczą miejsca powstawania fragmoplastów i stopnia ich rozwoju, natomiast faza mitozy, w której się różnicują, jest podobnie jak w materiale kontrolnym, związana $\mathrm{z}$ anafazowo-telofazowymi przemianami strukturalnymi chromosomów. Fragmoplasty tworzą się w miejscach zupełnie nieoczekiwànych i często odnosi się wrażenie, że ich pojawienie się nie jest związane $z$ obecnością wrzeciona mitotycznego. Powstałe fragmoplasty są wąskie, a przegrody pierwotne krótkie, niezupełne. W badanym materiale nie obserwowano występowania przegród całkowity.ch, dzielących komórkę macierzystą na dwie komórki potomne. Przegrody występują zwykle na peryferiach nieforemnych jąder poliploidalnych (Tabl. II, fig. 6; Tabl. III, fig. 6), pomiędzy grupami chromosomów (Tabl. IV, fig. 4-6), wewnątrz jąder (Tabl. V, fig. 6) lub odcinają bezchromatynowe tereny cytoplazmy (Tabl. V, fig. 2-4). Także w prawie normalnych anafazach przegrody nie są zupełne: mogą być zygzakowate, często na końcach zakrzywione czy rozszczepione (Tabl. V, fig. 2 i 5).

Glikozydy przedłużają czas podziału komórek bielma co najmniej dwukrotnie.

Wszystkie obserwowane układy chromosomów związane są z zaburzeniami w prometafazowych i anafazowych ruchach chromosomów. Zakłócenia w ruchach natomiast wskazują na nieprawidłowe funkcjonowanie wrzeciona mitotycznego. Zaburzenia w profazie i prometafazie pozwalają przypuszczać, że glikozydy oleandra hamują powstawanie i rozwój wrzeciona kariokinetycznego. Zakłócenia w anafazowych ruchach chromosomów są prawdopodobnie związane z dezorganizacją i inaktyrwacją wrzeciona już całkowicie uformowanego. Na czym polegają te uszkodzenia wykażą badania w mikroskopie elektronowym (szczegółowe wyniki są w przygotowaniu do druku).

Jakkolwiek przyjmuje się, że natura mikrotubul wrzeciona mitotycznego i fragmoplastu jest taka sama, to otrzymane wyniki wskazują, że mikrotubule fragmoplastu są mniej wrażliwe na działanie glikozydów niż mikrotubule wrzeciona mitotycznego. 